\title{
AN ANALYSIS OF THE APPLICABILITY OF THE OECD MOdel TAX CONVENTION TO NON-OECD MEMBER COUNTRIES: THE SOUTH AFRICAN CASE
}

\author{
Lee-Ann Steenkamp* \\ University of Stellenbosch Business School (USB)
}

Received: November 2015

Accepted: May 2016

\begin{abstract}
Most tax treaties (including South Africa's) are based on the 0ECD Model Tax Convention on Income and Capital and the related Commentary (the 'OECD Model'). Notwithstanding the uncertainty surrounding its legal status, the courts in many countries use the OECD Model in the interpretation of their tax treaties. The $0 E C D$ launched an action plan on Base Erosion and Profit Shifting ('BEPS') in 2013, which is aimed at improving international tax cooperation between governments. In South Africa, the importance of combating BEPS is highlighted by the fact that the Davis Tax Committee has appointed a sub-committee specifically to address concerns pertaining to BEPS. South Africa's participation in the BEPS project and its tax treaty negotiations with other countries, especially $0 E C D$ member states, are of the utmost importance to South Africa's National Treasury. Consequently, it is the primary objective of this article to analyse the applicability of the OECD Model to non-0ECD member countries, with particular emphasis on South Africa. It will be argued that, if the treaties of non-member countries are in conformity with the OECD Model and no specific position has been taken, the non-members also accept the provisions of the Model and the Commentary as an interpretative aid.
\end{abstract}

Keywords

Base Erosion and Profit Shifting; BEPS; double tax agreement; interpretation; 0ECD Model Tax Convention; tax treaty

\footnotetext{
*Ms L Steenkamp is a senior lecturer at the University of Stellenbosch Business School (USB), Stellenbosch University, Stellenbosch, South Africa. [lee-ann.steenkamp@usb.ac.za]
} 


\section{BACKGROUND AND FORMULATION OF THE STUDY}

\subsection{Introduction}

A surge in international trade and investment flows (UNCTAD, 2014) has obvious tax consequences, and the tax treatment of income resulting from these cross-border transactions is affected by tax treaties (Brooks, 2009:1). More than 3000 bilateral tax treaties have been signed to date (Lang \& Owens, 2014:6), with South Africa having approximately 80 double tax agreements ('DTAs') in force (SARS, 2015).

The Organisation for Economic Cooperation and Development ('OECD') notes that, in the changing international tax environment, concerns exist about how international standards on which DTAs are based allocate taxing rights between source and residence states (OECD, 2013a:11). Consequently, the $0 \varepsilon C D$ launched an action plan on Base Erosion and Profit Shifting ('BEPS') in 2013, which is aimed at improving international tax cooperation between governments (OECD, $2013 \mathrm{~b}: 13$ ). Although the BEPS project is orchestrated by the OECD, there has been some participation by over 80 developing countries and other non-OECD countries (OECD, 2016a). This is largely due to the fact that the BEPS initiative was endorsed by the governments of the G20 countries, which extended its application to some non-0ECD countries.

In South Africa, the importance of combating BEPS is highlighted by the fact that the Davis Tax Committee has appointed a sub-committee specifically to address concerns pertaining to BEPS. The Davis Tax Committee (2014:17) points out that the BEPS Action Plan entails various issues that fall under international law, especially matters that are dealt with in the context of DTAs. South Africa's participation in the BEPS project and its tax treaty negotiations with other countries, especially OECD member states, are clearly of foremost importance for South Africa's National Treasury.

\subsection{Research objective}

Notwithstanding that the OECD Model Tax Convention on Income and Capital 2014 and related Commentary (the '0ECD Model') can be of great assistance in the application and interpretation of tax treaties and in the settlement of disputes, it will be seen that their legal relevance remains a globally contentious point. As such, it is the primary objective of this article to analyse the applicability of the OECD Model to non-0ECD member countries, with particular emphasis on South Africa. In furtherance of this goal, a synthesis of scholarly opinions will be examined.

\subsection{Research method}

An interpretive research approach will be adopted for this study, as it seeks to understand and describe (Babbie \& Mouton, 2009). As with most legal interpretive research, this study adopts a doctrinal research methodology, as it provides a systematic exposition of the rules governing a particular legal category (in this case, the legal rules pertaining to the 0ECD Model), explains areas of difficulty and is based purely on documentary data (McKerchar, 2008).

This desktop study entails a literature review of and reference to both foreign and local statutory laws, tax treaties and policy documents, as well as authoritative studies on model tax conventions and double tax agreements. The documentary data to be used will be obtained from published articles, chapters in books, journal and legal databases and reputable websites. The research will reflect the law and policy developments up to and including 30 April 2016, except in certain 
circumstances where more recent policy developments or tax amendments appear particularly relevant.

\section{MODEL TAX CONVENTIONS}

\subsection{The more prominent models}

In an attempt to achieve a degree of standardisation of the contents of treaties by their members, model tax conventions were published by international organisations (Olivier \& Honiball, 2011:268). Consequently, in 1963, the OECD Model was prepared by developed countries of the world and it thus embodies rules and proposals by capital exporting countries (Oguttu, 2007:242). As it was drafted by representatives of major Western industrialised countries, lower-income, developing countries were concerned that it resulted in too large a reduction in source country tax (Brooks, 2009:2).

The developing countries responded to the success of the OECD Model by developing their own model convention under the auspices of the United Nations (UN) in 1980. This model was drafted between developed and developing countries and attempts to reflect the interests of developing countries (Oguttu, 2007:242). Although it is based upon the 0ECD Model, the UN Model Double Taxation Convention between Developed and Developing Countries (the 'UN Model') retains much greater source country taxation.

According to Rohatgi (2002:60), the UN Model has been criticised for not making a significant contribution to tax treaties; an obvious reason for this viewpoint could be ascribed to the fact that, since 1998, the UN Model has followed the changes in the OECD Model. Steenkamp (2013:1109) argues that the acceptance of the OECD Model over other available standards, like the UN Model, for example, could also possibly be explained by the fact that the OECD Model is sponsored by the most developed countries of the world, which are, not coincidentally, also the major capital exporting countries.

The third prominent tax treaty model is the United States model, which is followed by most treaties that the USA has signed with other countries, including South Africa (Oguttu, 2007:242). In addition, Olivier and Honiball (2011:272) make mention of South Africa's own model tax convention (Parliamentary Monitoring Group, 2005), which is used as a basis for treaty negotiations. Admittedly, it could be considered somewhat pretentious for a small country like South Africa to have its own model, but it is 'right and proper' for any country to have a template as its starting point for treaty negotiations (Mazansky, 2009:148).

Also worth mentioning is that the Southern African Development Community ('SADC') published a draft of its own model tax convention in 2001. Once the SADC model is finalised and ratified by all its members, South Africa (as member of the SADC) could use the SADC model as a basis for its negotiations (Olivier \& Honiball, 2011:272).

\subsection{The accompanying Commentary}

It has been the practice of the UN and the OECD that model tax conventions are all accompanied by Commentary notes, which are regularly updated approximately every two years (Ward, 2006:97). The 0ECD Model Commentary often goes beyond merely explaining the meaning of terms found in the OECD Model - it also provides the background to provisions and explains why certain 
provisions were considered desirable or necessary (Ellis, 2002:618). Countries may enter reservations to the articles of the OECD Model in order to preserve their freedom to depart from the $0 \varepsilon C D$ Model and they may also enter observations to the Commentary to indicate how they will apply the provisions of a particular article (Baker, 2002:para A.08).

The Commentary has been drafted and agreed upon by the experts appointed to the 0ECD's Committee on Fiscal Affairs and is generally regarded as playing a significant role in the development of international fiscal law (0ECD Model, Introduction:para 29). Tax administrations routinely consult the Commentary in their interpretation of bilateral tax treaties, taxpayers use it in conducting their businesses and planning transactions and investments, and the courts are increasingly using the Commentary in reaching their decisions (OECD Model, Introduction:para 29).

In recognition of the need to address new tax issues that arise in connection with the evolution of the global economy, the OECD released the contents of the 2014 update to the OECD Model on 16 July 2014. Previous updates were published in 1994, 1995, 1997, 2000, 2003, 2005, 2008 and 2010. While this recent update affects both the Articles of the 0ECD Model and the Commentary, most of the changes are in respect of the Commentary. This article is based on the 2014 OECD Model and Commentary.

TABLE 1: 0\&CD member countries

\begin{tabular}{|c|c|c|c|c|c|}
\hline No. & Country & $\begin{array}{c}\text { Year of } \\
\text { membership }\end{array}$ & No. & Country & $\begin{array}{c}\text { Year of } \\
\text { membership }\end{array}$ \\
\hline 1 & Australia & 1971 & 18 & Japan & 1964 \\
\hline 2 & Austria & 1961 & 19 & Korea & 1996 \\
\hline 3 & Belgium & 1961 & 20 & Luxembourg & 1961 \\
\hline 4 & Canada & 1961 & 21 & Mexico & 1994 \\
\hline 5 & Chile & 2010 & 22 & Netherlands & 1961 \\
\hline 6 & Czech Republic & 1995 & 23 & New Zealand & 1973 \\
\hline 7 & Denmark & 1961 & 24 & Norway & 1961 \\
\hline 8 & Estonia & 2010 & 25 & Poland & 1996 \\
\hline 9 & Finland & 1969 & 26 & Portugal & 1961 \\
\hline 10 & France & 1961 & 27 & Slovak Republic & 2000 \\
\hline 11 & Germany & 1961 & 28 & Slovenia & 2010 \\
\hline 12 & Greece & 1961 & 29 & Spain & 1961 \\
\hline 13 & Hungary & 1996 & 30 & Sweden & 1961 \\
\hline 14 & Iceland & 1961 & 31 & Switzerland & 1961 \\
\hline 15 & Ireland & 1961 & 32 & Turkey & 1961 \\
\hline 16 & Israel & 2010 & 33 & United Kingdom & 1961 \\
\hline 17 & Italy & 1961 & 34 & United States & 1961 \\
\hline
\end{tabular}

Source: OECD (2016) 
Most treaties are based on the OECD Model, including treaties entered into between non-0ECD member states (Olivier \& Honiball, 2011:271). The OECD (2015b) currently has 34 members, mainly representing the major industrialised countries. TABLE 1 indicates the member countries and the year each one joined the $0 \varepsilon C D$. It should be noted that South Africa is not a member of the OECD.

The OECD Model Commentary has become increasingly important in the interpretation and application of DTAs (Brincker, 2010:para 12.11.2). As a result, the OECD opened up the Commentary in 1999 to major non-member countries, including South Africa (Brincker, 2010:para 12.11.2). Although the countries generally agree with the text of the articles of the OECD Model and with the interpretation as explained in the Commentary, each country has been afforded the opportunity to indicate where it disagrees with the text of an article or an interpretation given in the Commentary (Brincker, 2010:para 12.11.2). Since 1999, 33 non-member countries have indicated their position on the OECD Model (OECD Model, Non-OECD economies' positions on the $0 \varepsilon C D$ Model tax convention). TABLE 2 catalogues the non- $0 E C D$ member countries whose positions are reflected in the $0 \varepsilon C D$ Model.

\section{TABLE 2: Non-OECD countries whose positions are reflected in the OECD Model}

\begin{tabular}{llll}
\hline No. & Country & No. & Country \\
\hline 1 & Albania & 18 & Latvia \\
2 & Argentina & 19 & Lithuania \\
3 & Armenia & 20 & Malaysia \\
4 & Azerbaijan & 21 & Morocco \\
5 & Belarus & 22 & People's Republic of China \\
6 & Brazil & 23 & Philippines \\
7 & Bulgaria & 24 & Romania \\
8 & Colombia & 25 & Russia \\
9 & Croatia & 26 & Serbia \\
10 & Democratic Republic of Congo & 27 & Singapore \\
11 & Gabon & 28 & South Africa \\
12 & Georgia & 29 & Thailand \\
13 & Hong Kong, China & 30 & Tunisia \\
14 & India & 31 & Ukraine \\
15 & Indonesia & 32 & United Arab Emirates \\
16 & Ivory Coast & 33 & Vietnam \\
\hline 17 & Kazakhstan & & \\
\hline
\end{tabular}

Source: OECD Model: Non-OECD economies' positions on the OECD Model Tax Convention

Although South Africa is not a member of the OECD, it was awarded observer status on the Committee on Fiscal Affairs in 2004 (OECD, 2004). The importance of this relationship is affirmed by the $0 \varepsilon C D$, which stated that South Africa is a key partner in the 0ECD's work (OECD, 2015a). This means that South Africa participates in some of the $0 E C D$ 's activities, including adherence to OECD instruments and sector-specific peer reviews. 
Notwithstanding this constructive relationship between the $0 E C D$ and South Africa, given that South Africa is not a member country, the legal status of the OECD Model and Commentary in South Africa is debatable. This matter will be addressed in the following paragraph.

\section{APPLICABILITY TO NON-OECD MEMBER COUNTRIES}

The Committee on Fiscal Affairs is the main forum for the 0ECD's discussions on taxation, covering international and domestic tax issues and tax policy and administration (OECD, 2013b). It has an extensive partnership programme with non-OECD countries that enables them to participate in the development of international tax arrangements. This partnership is implemented by means of multilateral, regional and bilateral programmes (OECD, 2013b).

The $0 \varepsilon C D$ states that most bilateral tax treaties follow both the principles and the detailed provisions of the $0 E C D$ Model and depicts the model as having considerable influence on the bilateral treaties between non-0ECD countries (OECD, 2012:81). Per the OECD (2012:82), nearly 400 treaties between $0 E C D$ member countries and over 3000 worldwide are based on the OECD Model.

The legal analysis concerning the interpretation of tax treaties could be different, depending on whether the contracting states are 0ECD member countries, non-0ECD countries that have officially determined and recorded their position on the OECD Model and Commentary, or third (other) countries (Erasmus-Koen \& Douma, 2007:340).

In an attempt to facilitate the role of the OECD Model as a standard to prevent double taxation in treaties where non- $0 \varepsilon C D$ countries are involved, the $0 E C D$ engages in an inclusive dialogue with non-0ECD countries to discuss developments in the Model and issues related to the negotiation, application and interpretation of bilateral treaties (OECD, 2012:82).

It should be noted that para 3 of the Introduction to the 0ECD Model refers exclusively to the application of tax treaties by the OECD member countries, wherein their tax authorities are instructed to:

[F]ollow these Commentary, as modified from time to time and subject to their observations thereon, when applying and interpreting the provisions of their bilateral tax conventions that are based on the Model Convention.

However, a section of the OECD Model is allocated to take into account opinions expressed by non$0 \varepsilon C D$ member countries, titled 'Non-OECD economies' positions on the OECD Model tax convention' (Non-OECD section). The Committee on Fiscal Affairs' work programme is carried out by various groups of national experts. According to the OECD (2012:11), one such unit is the Advisory Group for Co-operation with Non-0ECD Economies, which acts as a forum to obtain the perspectives of non-0ECD partners in the development of the work of the Committee on Fiscal Affairs, as well as the direction and strategic orientations of the Global Relations programme of events.

The Committee on Fiscal Affairs decided in 1991 that, because the influence of the model tax convention had extended far beyond the $0 E C D$ member countries, the ongoing process through which the Model would be updated should be opened up to benefit from the input of non-0ECD economies. Consequently, in 1996, annual meetings were organised which allowed experts of member countries and certain non-0ECD countries to discuss issues related to the negotiation, application and interpretation of tax conventions. 
At the same time, it was recognised that these countries should also have the opportunity to identify areas where they are unable to agree with the text of an Article or with an interpretation given in the Commentary (0ECD Model, Non-OECD section:paras 1-2). While these countries generally agree with the text of the Articles of the OECD Model and with the interpretations put forward in the Commentary, there are some areas of disagreement for each economy (OECD Model, Non-0ECD section:para 5). For example, Indonesia and the People's Republic of China expressly clarified that, in the course of negotiations with other countries, they would not be bound by their stated positions included in this section.

As the OECD Model and Commentary are addressed to the OECD member countries, it could be contended that there is little legal ground for arguing that the positions of non-OECD countries are implicitly reiterated upon the conclusion of a tax treaty (Maisto, 2005:18). On the other hand, various scholars have argued that the Commentary updates on the OECD Model provide strong evidence that the parties to a DTA, particularly if both are $0 E C D$ member countries - but also nonmember countries, if they followed the OECD Model -intend that the meaning established in the Commentary should apply (Sada Garibay, 2011:4).

In the context of tax avoidance, with respect to the interpretation of tax treaties entered into after January 2003, the revisions to the Commentary on Art 1 of the 0ECD Model will generally be taken into account and given substantial weight by the tax authorities and courts of both OECD and non-OECD countries (Arnold, 2004:258). The effect of the OECD Model Commentary goes beyond the treaties concluded between the $0 \varepsilon C D$ member countries, because (Martín Jiménéz, 2004:28):

[T] he OECD pretends to confer interpretative value on the Commentary with regard to the treaties concluded between OECD countries and non-OECD countries and even to the treaties concluded between two non-OECD countries if the particular treaty provision follows the wording of the OECD Model.

However, notwithstanding the fact that the Commentary can play a role in the interpretation of tax treaties with non-OECD members, it is 'certainly not a decisive one' (Wattel \& Marres, 2003:226). Yet, this role could be decisive if the non-member country involved has determined its position with respect to this version of the Commentary without making any observation or reservation (Wattel \& Marres, 2003:226). Engelen and Pötgens (2000:266) quote a number of authoritative legal scholars in support of the consensus on the importance of the Commentary for interpretation uses by non-0ECD member countries, citing, amongst others, Ward (1996:36):

In fact, the 0ECD Model has become so widely used by non-0ECD member countries that it can be presumed that the Commentary provides good evidence of all treaty partners' understanding of treaty terms based on the Model.

Nevertheless, the vague and diplomatic language of the Commentary (which is derived from the fact that the $0 \varepsilon C D$ member countries wish it to be non-binding) could cause another issue to arise: it would be politically questionable as to how far a choice to govern an important aspect of two sets of tax treaties, unrelated to the OECD Model and the Commentary, would comply with the purpose of the $0 \varepsilon C D$ (Cerioni, 2007:382). This could also have political implications for non-0ECD countries and could place increased pressure on compliance.

Horner (2001:179) suggests the use of an international tax organisation (apart from the 0ECD) to take into account the interests of non-OECD countries - especially those of developing countries. The UN Model might provide a way out of this dilemma, but its efficacy is somewhat doubtful. 
Another practical difficulty relates to response times, as governments and the OECD have to respond more quickly to changing business models (Owens, 2006:558). In order to achieve such a timeous response, enhanced dialogue between business and governments, closer cooperation and the involvement of all the main players - regardless of whether they are $0 E C D$ or non-OECD countries - is to be recommended (Owens, 2006:558). Indeed, one of the core issues in the 0ECD's current tax agenda is the use of tax conventions in the removal of barriers to trade and investment and how to take into account non-OECD countries' views in the development of the OECD Model (OECD, 2012:85).

To this end, the Committee on Fiscal Affairs is supported by the Centre for Tax Policy and Administration, whose 'Global Relations Programme' acts as a bridge between $0 \varepsilon C D$ member countries and partner countries outside the OECD. One of the objectives of this programme is to ensure that non-OECD countries have a voice in developing international tax standards and guidelines so that these continue to be of wide relevance and practical use to all in an increasingly interdependent global economy (OECD, 2012:143).

A concomitant obstacle is created by the practice of the courts of both OECD and non-OECD countries of referring to the $0 E C D$ Model and the Commentary. This increasing involvement of non$0 \varepsilon C D$ countries reveals the need for more legal certainty, which can only be attained by clear texts and guidance in the Commentary (De Goede, Kaur, Kosters \& Perdelwitz, 2012:314). One of the topics discussed at the 2001 International Bureau of Fiscal Documentation ('IBFD') seminar in Amsterdam on the future of tax treaties was the involvement of non- $0 \varepsilon C D$ member countries and how international coordination and cooperation with respect to tax treaties could be enhanced. In the summary of the proceedings, the participation of non-member countries is addressed as follows (Arnold, Sasseville \& Zolt, 2002:98):

\begin{abstract}
And the recent standard consultations with selected non-member countries on the text of the OECD Model and Commentary, resulting in reservations and observations that these countries file with the $0 \varepsilon C D$, has substantially widened the involvement of these countries in the OECD Model and Commentary. Still, as these countries do not participate in the preparation of the changes and additions to the OECD Model and Commentary, they cannot directly contribute to the deliberations that produce these changes and additions.
\end{abstract}

The quandary faced by non-member countries is obvious: although they are consulted by the OECD to some extent, they cannot participate in the amendments and additions to the OECD Model. Despite not being a member of the $0 \varepsilon C D$, most of South Africa's treaties largely follow the OECD Model guidelines, as these are regarded as important and influential (Oguttu, 2007:242; Haupt, 2014:493). If the treaties of non-member countries are in conformity with the OECD Model and no specific position has been taken, the non-members also accept the provisions of the Model and the Commentary as an interpretative aid (Wattel \& Marres, 2003:224).

A related point of ambiguity regarding the use of the 0ECD Model Commentary is the version that ought to be used in the interpretation process. This is the subject matter of another article.

\title{
4. CONCLUSION
}

The inclusion of the positions of non-OECD countries reflects the growing need to take account of the views of non-member countries in the development of the internationally agreed standards included in the OECD Model (OECD, 2013c). The time and effort spent by the OECD in assisting non$0 \varepsilon C D$ countries to develop their tax treaty network is to be lauded. Ultimately, developing economies, such as South Africa, can benefit from the BEPS project and OECD standards on tax 
governance (as embodied in the 0ECD Model) by participating in global tax governance as well as modernising their own anti-tax evasion systems (Zhu, 2016:4).

It was demonstrated in this article that if the treaties of non-member countries are in conformity with the $0 \varepsilon C D$ Model and no specific position has been taken, the non-members also accept the provisions of the Model and the Commentary as an interpretative aid. Also, where a non-member has taken an official position on the $0 \varepsilon C D$ Model Commentary, it has more 'political and moral obligation' to adhere to its position as opposed to countries which did not set any position (Kinkladze, 2012:32). Consequently, the persuasive value of the Commentary can differ between OECD member and non-member states.

\section{LIST OF REFERENCES}

Arnold, B.J. (2004). Tax treaties and tax avoidance: the 2003 revisions to the Commentary to the 0ECD Model. Bulletin for International Taxation, 58(6), pp. 244-260.

Arnold, B.J., Sasseville, J. and Zolt, E.M. (2002). Symposium: Summary of the Proceedings of an Invitational Seminar on Taxation of Business Profits Under Tax Treaties. Canadian Tax Journal, 50(6), pp. 1979-2024.

Babbie, દ. and Mouton, J. (2009). The practice of social research. Cape Town: Oxford University Press.

Baker, P. (2002). Double Tax Conventions: a manual on the OECD Model Tax Convention on Income and on Capital, $3^{\text {td }}$ edition. United Kingdom: Sweet \& Maxwell Ltd.

Brincker, $\varepsilon$. (2010). Chapter 12: The conclusion and force of double taxation agreements. In De Koker, A.P. \& Brincker, $\varepsilon$. (eds.) Silke on Internationa/ Tax. Durban: LexisNexis.

Brooks, K. (2009). Canada's evolving tax treaty policy toward low-income countries. In Cockfield, A.J. (ed.) Globalization and the impact of tax on international investments. Canada: University of Toronto Press.

Cerioni, L. (2007). A hypothesis for radical tax reform in the European Union - the implications of the abolition of corporate income taxes. European Taxation, 47(8/9), pp. 377-388.

Davis Tax Committee. (2014). Addressing base erosion and profit shifting in South Africa - Davis Tax Committee interim report. Available:

http://www.taxcom.org.za/docs/New_Folder/1\%20DTC\%20BEPS\%20Interim\%20Report\%20\%20The\%20Introductory\%20Report.pdf. (Accessed 16 July 2015).

De Goede, J., Kaur, D., Kosters, B. and Perdelwitz, A. (2012). Interpretation and application of Article 5 (Permanent Establishment) of the OECD Model Tax Convention: response from IBFD research staff. Bulletin for International Taxation, 66 (6), pp. 313-318.

$\varepsilon l$ is, M.J. (2002). The influence of the $0 E C D$ Commentaries on treaty interpretation - response to Prof Dr Klaus Vogel. Bulletin for International Taxation, 54(12), pp. 617-618.

Engelen, F.A. and Pötgens, F.P.G. (2000). '0ECD Report on "The application of the 0ECD Model Tax Convention to Partnerships" and the Interpretation of Tax Treaties' European Taxation, 40(7), pp. 250-269.

Erasmus-Koen, M. and Douma, S. (2007). Legal status of the OECD Commentary - in search of the Holy Grail. Bulletin for International Taxation, 61 (8), pp. 339-352.

Haupt, P. (2014). Notes on South African Income Tax, $3^{\text {td }}$ edition. Roggebaai: Hedron. 
Horner, F.M. (2001). Do we need an international tax organisation? Tax Notes International, 24(8), pp. 179-187.

Kinkladze, D. (2012). Squaring the Circle: The Role of the OECD Commentaries for the Interpretation of Tax Treaties between the OECD and non-OECD States. Masters thesis. Sweden: Lundt University.

Lang, M. and Owens, J.P. (2014). The role of tax treaties in facilitating development and protecting the tax base. WU International Taxation Research Paper Series, 2014-03.

Maisto, G. (2005). The observations on the 0ECD Commentary in the interpretation of tax treaties. Bulletin for International Taxation, 59(1), pp. 14-19.

Mazansky, દ. (2009). South Africa's treaty network - why is South Africa the meat in the sandwich? Bulletin for International Taxation, 63(4), pp. 145-151.

McKerchar, M. A. (2008). Philosophical paradigms, inquiry strategies and knowledge claims: applying the principles of research design and conduct to taxation. Inquiry Strategies and Knowledge Claims: Applying the Principles of Research Design and Conduct to Taxation, 5-22.

Oguttu, A.W. (2007). Curbing 'treaty shopping': the beneficial ownership' provisions analysed from a South African perspective. Comparative and International Law Journal of Southern Africa, 40(2), pp. 237-258.

Olivier, L. and Honiball, M. (2011). International tax: a South African perspective, 5th edition. Cape Town: Siber Ink.

Organisation for Economic Cooperation and Development (OECD). (2004). China, South Africa to participate in work of OECD's Committee on Fiscal Affairs. Available:

http://www.oecd.org/newsroom/chinasouthafricatoparticipateinworkofoecdscommitteeonfiscalaff airs.htm (Accessed 24 June 2013).

Organisation for Economic Cooperation and Development (OECD). (2012). OECD's current tax agenda - 2012. Available: http://www.oecd.org/tax/OECDCurrentTaxAgenda2012.pdf (Accessed 12 September 2013).

Organisation for Economic Cooperation and Development (OECD). (2013a). OECD invites India to participate in its Committee on Fiscal Affairs. Available:

http://www.oecd.org/ctp/oecdinvitesindiatoparticipateinitscommitteeonfiscalaffairs.htm (Accessed 24 June 2013).

Organisation for Economic Cooperation and Development (0ECD). (2013b). Action plan on base erosion and profit sharing. Available: http://www.oecd.org/ctp/BEPSActionPlan.pdf (Accessed 24 May 2014).

Organisation for Economic Cooperation and Development (OECD). (2013c). International Regulatory Co-operation: Case studies, Vol. 1: Chemicals, consumer products, tax and competition. Paris: OECD Publishing.

Organisation for Economic Cooperation and Development (OECD). (2014). Model Tax Convention on Income and on Capital. Available: www.oecd.org/ctp/treaties/2014-model-tax-conventionarticles.pdf (Accessed l August 2015).

Organisation for Economic Cooperation and Development (OECD). (2015a). The OECD's relations with its key partners. Available: http://www.oecd.org/general/theoecdsrelationswithitskeypartners.htm. (Accessed 2 August 2015).

Organisation for Economic Cooperation and Development (OECD). (2015b). Members and partners. Available: http://www.oecd.org/about/membersandpartners/. (Accessed 3 August 2015). 
Organisation for Economic Cooperation and Development (OECD). (2016a). Developing countries and BEPS. Available: http://www.oecd.org/tax/developing-countries-and-beps.htm. (Accessed 30 April 2016).

Organisation for Economic Cooperation and Development (OECD). (2016b). 'List of OECD Member countries - ratification of the Convention on the OECD. Available:

http://www.oecd.org/about/membersandpartners/list-oecd-member-countries.htm. (Accessed 30 April 2016).

Owens, J. (2006). International taxation: meeting the challenges - the role of the 0ECD. European Taxation, 46(12), pp. 555-558.

Parliamentery Monitoring Group. (2005). South African Model Tax Convention. Available: http://www.pmg.org.za/docs/2005/050817oecdmalaysia.pdf. (Accessed 20 April 2015).

Rohatgi, R. (2002). Basic international taxation, volume 412. London: Kluwer Law International.

Sada Garibay, M. (2011). International/OECD - An analysis of the case law on Article 3(2) of the OECD Model (2010). Available: http://online.ibfd.org/kbase. (Accessed 3 April 2015).

South African Revenue Service (SARS). (2015). Double taxation agreements (DTAs) and protocols. Available: http://www.sars.gov.za/Legal/International-Treaties-Agreements/DTA-

Protocols/Pages/default.aspx. (Accessed 30 July 2015).

Steenkamp, L.A. (2013). Beneficial ownership provisions in tax treaties between developed and developing countries: the Canada/South Africa example. International Business \& Economics Research Journal, 12(9), pp. 1107-1118.

United Nations Conference on Trade and Development (UNCTAD). (2014). World Investment Report. Available: http://unctad.org/en/pages/PublicationWebflyer. aspx?publicationid=937. (Accessed 19 March 2015).

Ward, D.A. (1996). Ward's Tax Treaties, 1996-97. Toronto: Carswell.

Ward, D.A. (2006). The role of the Commentary on the 0ECD Model in the tax treaty interpretation process. Bulletin for International Taxation, 60(3), pp. 97-102.

Wattel, P.J. and Marres, 0. (2003). The legal status of the OECD Commentary and static or ambulatory interpretation of tax treaties. European Taxation, 7(43), pp. 222-235.

Zhu, J. (2016). G20 institutional transition and global tax governance. The Pacific Review, pp. 1-7. 